\title{
DST wt Allele
}

National Cancer Institute

\section{Source}

National Cancer Institute. DST wt Allele. NCI Thesaurus. Code C104890.

Human DST wild-type allele is located in the vicinity of $6 \mathrm{p} 12.1$ and is approximately 497 $\mathrm{kb}$ in length. This allele, which encodes dystonin protein, is involved in the structure of cytoskeleton networks. Mutations in this gene are associated with Hereditary Sensory and Autonomic Neuropathy Type VI. 